〔論説〕特集/拡散するアーバンフリンジにおける土地利用管理の新展開

\title{
農振法にもとづく土地利用コントロール
}

\section{A Method for Controlling Land Use on The Agriculture Promo- tion Areas Act}

Narufumi FUKUYO : Hokkaido National Agricultural Experiment Station

福与 徳文

The purpose of this paper is to propose a method for controlling land use on the Agriculture Promotion Areas Act. Our proposals are as follows.

1. It is important to manage rezoning from Agricultural Land Zone to "The Other Zone" in Agriculture Promotion Area. The rezoning system, however, is not established in Japan. So, local governments have to make rezoning ordinances for themselves.

2. Rezoning ordinances should contain regulations controlling the size and location of new development.

3. Rezoning ordinances will be more effective in controlling land use on the fringe of urban areas, if they are accompanied with the plan of new development and the exchange of lands.

Keyword: The Agriculture Promotion Areas Act, zoning, agricultural land zone, the "other zone" in an agriculture promotion area

農振法, ゾーニング, 農用地区域, 農振白地

\section{はじめに}

農業振興地域の整備に関する法律(以下, 農振法) のゾーニング站に対しては，いままで様々な問題 点が指摘されてきた。筆者も制度の問題点につい て整理を試みたことがあるが1)，農村計画法 (ある いは農村整備法)への脱皮といった制度の根本的な 変革にはまだまだ時間が必要なようである。そこ で本稿では,「現行農振制度の枠内で市町村が独自 の工夫を行ってアーバンフリンジの土地利用をコ ントロールしようとすれば，どういった方法が有 効か」を述べることとする。

制度の運用面にスポットをあてるのは, (制度の
抜本的な改正には時間が必要だから）当面は運用で 切り抜けるといった”次善の策”的な理由からだ けではない。あとで詳しく述べるが, 農振法のゾ ーニングは市町村の運用次第でその成否が大きく 左右されるのである。しかも，この傾向は今後ま すます強まる。というのは，地方分権化の流れの 中で農振法のゾーニングも機関委任事務から自治 事務に変わり, 市町村の責任が一層重くなるから である。

\section{1.鍵をにぎる農用地区域からの除外}

ここで「釈迦に説法」と叱られることを恐れず に, 農振法のゾーニングの概要を簡単にふりかえ

*福与德文（ふくよ なるふみ）・農林水産省北海道農業試験場 
つておく。

\section{(1)創設の経緯}

農振法は，まさに高度経済成長の直中，工業開 発や住宅開発によって農地が無秩序に潰廃されて いく事態に対応して創設された。スプロールの防 止策としては，既に農地法の農地転用許可基準 (1959) が設けられていたが, 同基準は一筆ごとに 転用の可否を判定する「一筆統制」の方法をとっ ており，優良農地を面的に確保するといった点で は不十分であった。そこで，ゾーニング手法の制 度化に期待がかかっていたのである。

農振法制定の直接の契機となったのは，1967年 の新都市計画法の国会提出である。提出された都 市計画法案には，市街化区域・市街化調整区域と いったゾーニング制度が盛り込まれていたが，市 街化区域の設定によって開発を行う土地をあらか じめ確保する「都市サイドの領土宣言」として農 業サイドには受け止められた。そこで，農業サイ ドとしてはそれに対抗するために「農業サイドの 領土宣言」として農振法案を 1 年遅れで提出した のである。

\section{(2)内容}

農振法のゾーニングの内容を概括すると，次の ようになる。

(1)まず農業振與地域を指定して，その中に農用 地区域を設定する。この結果, 農業振興地域 は農用地区域とその他の区域に 2 区分される。 農業振興地域内のその他の区域を俗に農振白 地染 2 呼ぶ。

(2)農用地区域内は転用禁止である（農振法第17 条)。農用地区域内で転用したい場合, 予好当 該農地を農用地区域から除外しなければなら ない。

(3)農用地区域の設定基準の一つを「土地基盤整 備事業の対象地」とした。また，「土地基盤整 備事業は農用地区域を対象にする」といった 「メリット通達」注3が出された。これらにより 農用地区域の設定と土地基盤整備事業の優先
度がリンクした。

農振法のゾーニングをひとことでいえば，転用 禁止の農用地区域を設定し，それと土地基盤整備 の優先性をリンクさせることによって，優良農地 の面的な保全とその有効利用をはかるシステムと いえよう。したがって，農用地区域が適正に設定 されれば，あるいは農用地区域の変更が適切に行 われれば，優良農地を確保する目的は達成できる はずであった。

\section{(3)過大な白地・容易な除外}

ところが，本来，農用地区域に設定されるべき 農地が農用地区域に編入されず, 農家の開発期待 を受けて農振白地が肥大化しているのが現状であ

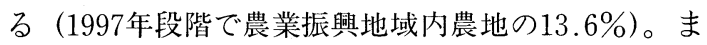
た, 農用地区域の变更（多くは農用地区域からの除 外）比較的容易に行われてしまうため, 集落土地 利用秩序に多大な影響を与えているのである。

農振法のゾーニングが優良農地の保全に有効に 機能するかどうかは，農用地区域の設定，あるい は農用地区域の変更のあり方如何にかかっており, それを実際に担うのは市町村なのである。ところ で, 農用地区域の設定自体は, 法制定後 5 年間に おおかたの市町村で完了している。したがって現 時点で最も問題なのは，農用地区域の変更，とり わけ農用地区域からの除外のあり方なのである。

\section{2. 農振除外の集落土地利用秩序への影響}

\section{(1)抽象的な除外位置の基準}

農用地区域からの除外（以下，農振除外）には， おおよそ 5 年ごとの大きな見直しである「特別管 理」によるものと, 農地転用の申請等に対応して 行う「一般管理」注4によるものがある。特別管理・ 一般管理のどちらによる場合でも，除外が忍可さ れるためには「5 要件」辛5 と呼ばれるハードルを越 えなければならない（表1）。

ところが， 5 要件のうち具体的かつ客観的判断 が容易なのは, 最初の「代替可能性 (申請者の所有 地の中に，申請地のほかに白地や市街化区域内の土地 
表 1 農振除外の 5 要件（47農政第1849号農政局長通達）

ア 農用地区域内の土地を農用地区域から除外する場合には，農用地区域外に代替すべき土地 がないものであること。

イ 可能な限り農用地区域の周辺部の土地等変更後の農用地区域の利用上の支障が軽微である 土地を除外するものであること。

ウ 変更後の農用地区域の集団性が保たれるものであること。

エ 変更後, 土地利用の混在が生じないことであること。

オ 国の直轄又は補助による土地改良事業, 農用地開発事業, 農業構造改善事業等によって土 地基盤整備事業を実施中の地区内の土地及び当該事業が完了した年度の翌年から起算して 8 年を経過していない地区内の土地を農用地区域から除外するものでないこと。
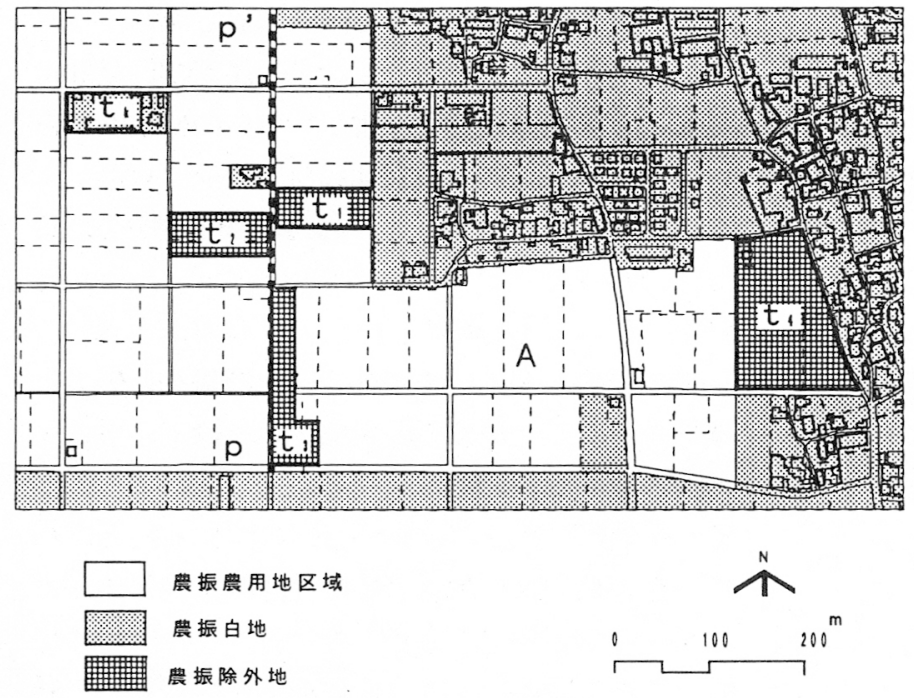

図 1 農振除外の集落土地利用への影響

がないか)」と, 最後の「土地基盤整備事業完了後 8 年未満の農地は不可 (俗にいう“8 年しばり”)」 である。土地利用秩序化にとって重要な「位置」 を制御する条件は，「利用上の支障が軽微」「集団 性が保たれる」,「土地利用の混在が生じない」と 理念を示すにとどまり，抽象的である。このため， 除外位置の適否については市町村担当者の主観的 判断に委対林。

こういった場合, 担当者の判断が一貫する保証 はない。あるケースでいったん緩い運用を行った ら, その後, それより厳しくすることは困難とな り，もっとも緩い運用が常態化してしまう。これ
が, 農用地区域を虫食い的に穴をあけ, 集落土地利用の秩序の摚乱要因となるの である。

(2)除外位置による土地利用秩序への影響 の違い

ここで，農振除外がその位置によって 集落の土地利用にいかなる影響を与える か, 具体的にみておこう2)。図 1 に示した のは，ある集落における農振除外の実態 である。ちなみに，この集落では土地基 盤整備事業が 8 年以上前に完了しており， “8 年しばり”の規制は受けない。

まず，除外 $\mathrm{t}_{1}$ に注目していただきた い。 $t_{1}$ は既存の農振白地と接続してお り, 空間的連続性からみると, 一見, そ れほど問題があるように見えない。判断 する人にもよるが,「利用上の支障が軽微」「集団 性が保たれる」,「土地利用の混在が生じない」と いった要件もクリアーしているといえなくもない。 そこで $t_{1}$ の除外が羿められたわけだが， $t_{1}$ には 土地利用秩序に対する直接的な影響のみならず, 将来の除外を誘発する作用があった。このことは, $\mathrm{t}_{1}$ の除外後, $\mathrm{t}_{2}, \mathrm{t}_{3}$ が相次いで除外されたこと をみても明らかである。というのは, $\mathrm{t}{ }_{1}$ の除外に よって, 農道 $\mathrm{p}-\mathrm{p}$ に接する他の農地の除外が申 請された場合にそれを拒否する根拠がなくなった からである(もし除外 $\mathrm{t}_{1}$ がなければ， $\mathrm{t}_{2}$ の除外が申 請されても, 既存の農振白地と接続していないため, 


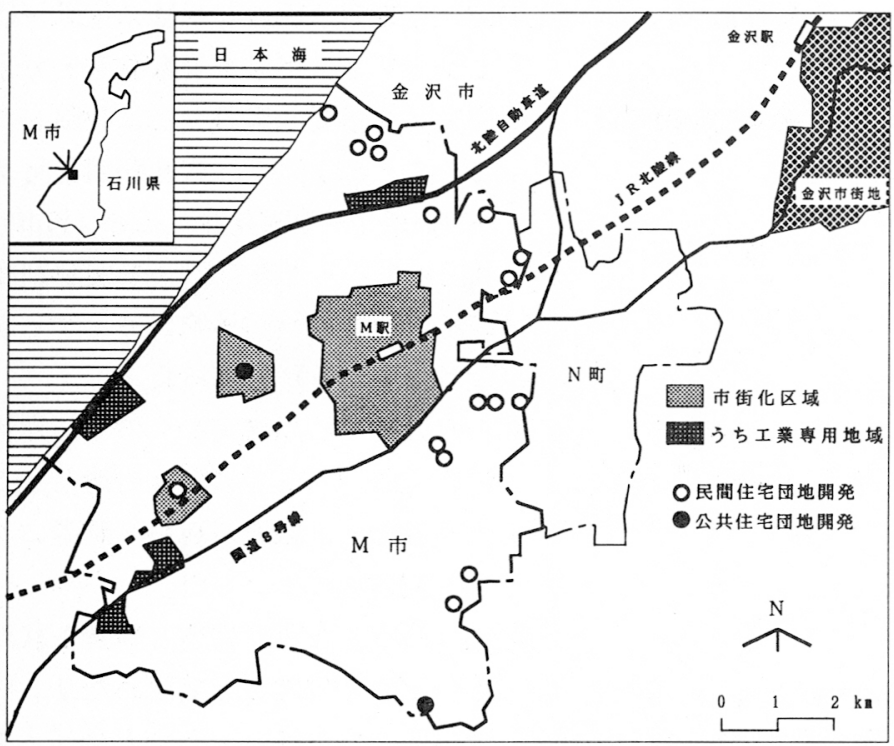

図 2 M市の位置と開発状況

「集団性を摚乱する」として拒否されただろう)。

また， $\mathrm{t}_{1}$ によって誘発された $\mathrm{t}_{3}$ は集落土地利 用にさらに深刻な打撃を与えた。 $\mathrm{t}_{3}$ の除外によっ て,これまで20ha を上回っていた農地集団が分断 され，小規模な団地 $\mathrm{A}$ を集落居住区の南側に生み 出してしまったのである。これによって, 団地 $\mathrm{A}$ は農地転用許可基準上の等級も下げることになり， 今後, 農振除外, 農地転用の申請がなされた場合, それを拒むのが困難になってしまったのである。

一方， $\mathrm{t}_{4}$ は集落居住区に接続し，その凹部を埋 める格好で除外された。このため, 空間構成の観 点から集落居住区の凹凸を解消するだけでなく, $\mathrm{t}_{1}, \mathrm{t}_{2}, \mathrm{t}_{3}$ と比べて農業生産条件に与えるイン パクトも小さいと考えられ，除外されたケースの 中では相対的に好ましい例といえよう。

このように, 農振除外は, その位置によってそ の後の土地利用に与える影響の大きさが異なる。 ところが，先に挙げた 5 要件の除外位置に対する 規定は抽象的で，そのままでは，集落土地利用に 障害をもたらすような除外を必ずしも排除できな い。題材になっていただいた市町村の名誉のため
にもいっておくが，これは特殊なケース ではなく，ごく平均的に農振地域の管理 を行っている市町村の例である。

したがって，除外位置を適正にコント ロールして集落の土地利用秩序を保つた めには，市町村が「位置」の具体的な規 準注6を国の基準である 5 要件に上乗せし て独自に作成することが必要となる。

\section{3。独自の規準を作成するための条件}

さて，除外位置を適正にコントロール するには，(1)どのような規準を作ればよ いか，(2)「建築の自由」のもとで自由を 制限する規準を運用していくための条件 とは何か, が重要な課題となる。このこ とを，一つの事例をとおして考えてみよ う。ここで取り上げるのは石川県M市の ケースである。M市は独自の規準を作成し，それ を市主導の計画的開発や土地交換と組み合わせて 総合的に運用した点に大きな特徵がある。なお， 事例の詳細については, 拙著「集落空間の土地利 用形成」2)を参照されたい。

\section{(1)石川県M市のケース}

M市は金沢市の西南に隣接し，高度経済成長期 以降，金沢市街地の外延的拡大の影響を受けて開 発が進んだ (図 2 )。とくに国道 8 号線のバイパス 整備 (1968) を境に, 沿道の一部でモーテル街が出 現するなど，乱開発の様相を呈しはじめていた。 当時は都市計画線引き前であったため, 開発許可 による規制も働かず，有効な対策を講じることが できなかった。これに危機感を持ったM市は, 農 振法のゾーニングを1972年に, 都市計画法のゾー ニングを1975年に行った。

1 ）市独自の農振地域管理

M市のゾーニングの特徵は，市全域を都市計画 区域に指定し，市街化調整区域と農振地域をまる ごと重複(農振地域二市街化調整区域)させたことで ある。これによって，農振地域内の転用に対して 
表 2 農振白地の設定方針（石川県M市1980年農振計画見直し時）

1. 転用希望と白地面積の一致

5 年以内の転用希望を集落単位にまとめ, この範囲で白地の設 定を認める。

2. 分家住宅目的の白地の制限

分家住宅目的の農地転用予定件数の累計合計が，集落農家戸数 を上回ることを禁止する。

3．農用地の一体性の保全

白地を集落居住区周辺へ集団化して設定する。

4。転用位置の居住環境への配慮

分家住宅や集落公共施設建設のための白地は，道路北側に設定 する(道路融雪のため)。

5 ．生活関連施設用地の集落住民負担

生活関連施設用地は，集落住民が共同負担する。

6. 工場・事業所目的の白地の原則禁止

工場・事業所の拡張・新設を，都市計画法の用途地域以外では 原則的に認めない。既存の施設の拡張に関しては，必要性・資 金計画・用地買収見込み等を検查して認める。

7. 白地の公平配分

できるだけ多くの農家に白地の保有機会を与える。

8. 都市施設整備と白地の整合性

幹線道路やガス・上下水道等の都市施設が整備されている地区 を優先的に白地とする。

*本表は，原資料2)の表現をわかりやすくしたもの。

は農地転用許可と開発許可の 2 重の規制が働くこ とになり，そのスプロール防止効果に期待したの である。しかし，期待と裏腹に，比較的広く設定 された農振白地（農振地域内農地の11\%）において バラ建ち的開発が進んでしまった。M市にとって 農振白地の縮小が，土地利用コントロールのため の優先課題となった。

\section{a．白地農用地の設定方針}

そこでM市は，1980年の農振計画見直し永7の際， 「農振白地の設定方針 (表 2)」を作成して，それま で広範に存在していた農振白地の縮小をはかった。 方針として明示することによって，市の考えを農 家に周知させたとともに, 担当者の判断にも客観 性・一貫性をもたらすことができた。

設定方針の特徴は次のとおりである。
(1)白地を開発予備地と明確に位置づけ, しかも将来の用途を農家住宅・分家 住宅・集落公共施設などに制限した。 このことによって，農地転用許可基 準 (農地法) や開発許可基準 (都市計 画法）といった既存の 1 筆統制制度 の不十分な点 (例外的に許可する用 途が多すぎる）を補つた。

(2) 5 年以内に転用確実なもので，集落 居住区周辺のものに限り白地として 認めるなど，白地の面積・位置に対 する制限を基本とした。

(3)集落の寄り合いで妥当と判断された ものだけを白地として認めたり，白 地所有の公平性をもとめるなど，集 落自治組織が伝統的にもつ調整機能 を活用した（市独自の規準の場合，法 による強制以外の条件づけが必要)。 この規準を用いて農振計画の見直しを 行った結果，農振地域内農地の $11 \%$ 占 める白地が $5 \%$ に縮小された。

b. 農振除外規準一二辺接続条件一

農振白地を必要最小限に抑制したため, 新たな開発需要が生じた場合，その用地を農振白

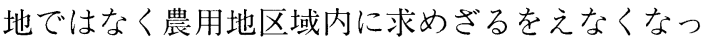
た。こういった場合, 農振除外位置のコントロー ルを適正に行わないと，せっかく農振白地を縮小 しても，白地という緩衝帯がないだけに，かえつ て集落土地利用秩序を混乱させる危険性があった。 ところが前述したように，5要件(表1)だけでは 除外位置のコントロールは難しいのである。

そこで，M市は 5 要件に「2 辺接続条件」を上 乗せした独自の除外規準を作成した。2 辺接続条 件とは，筆地の 1 辺が道路(原則幅員 $6 \mathrm{~m}$ 以上), も う 1 辺が道路または宅地に接続していることを除 外認可の要件とすることである。この規準は単純 明快で，除外位置の可否をどの担当者が判断して も客観的に行えることがその特徴である。 
この規準に従えば，図1のようなケースでも $\mathrm{t}_{1}, \mathrm{t}{ }_{2}$ の除外を防ぐことができる。ただし, 道路 と 2 辺接続するだけの除外も認めてしまったため, このままでは $\mathrm{t}{ }_{3}$ のような集落居住区から離れた 交差点に沿接する不適切な除外を排除できない。 これに対して M市は，2 辺が道路に接続する場合， 道路が交差する 4 つの角のうち集落居住区が存在 する側の角のみ認めるという付帯条件をつけた。 この付帯条件によって， $\mathrm{t}_{3}$ のような除外も防げる 仕組みになった。

2 ) 市主導の計画的開発

農振白地を縮小したり，農振除外を厳しく規制 することは，農家から転用機会を奪うことに繋が るので, 一般に, 農家にとって受け入れ難いもの である。また, 一定量以上の都市的開発需要が存 在する場合, 開発を抑制するだけは土地利用秩序 は保てないし，現実的ではない。

そこで，M市は個別小規模な開発を制限する一 方で，一定規模以上のまとまった開発を市主導で 計画的に誘導した。これは, 放置すれば分散的に 行われる小規模開発を適正な位置にまとめること によって，スプロール的な農地の潰廃を防止する とともに，良好な居住環境の効率的な形成を狙っ たものである。

開発区域は, 開発需要の高さ, 農家の開発期待 の高さ, 地域的均衡などに配慮して選定されるが, 集落境界上に複数集落を跨いで設定された点が大 きな特徵として挙げられる。これは, (1)集落境界 周辺は劣等農地であることが多いため, 農業生産 基盤への打撃が小さくすむ，(2)一つの開発で，で きるだけ多くの集落, 多くの農家の開発欲求を吸 収するためであった。

\section{3 ）土地交換}

開発をまとめて計画的に行うことは, 開発区域 内の土地所有者には売却機会を与えるが, 区域外 の土地所有者のそれを奪うことになる。一方，区 域内の土地所有者も全てが売却を望むわけではな く, 所有地の一部売却を望むに過ぎない場合が多
い。計画的開発が直面する最も大きな課題はまと まった用地の取得だが，このような問題が障害と なることが多い。また，この問題を抱えたままで 開発を進めても，区域外に土地売却を果たせなか った不満農家を残すことになり，彼らによる個 別・分散的な開発が続発する危険性が高い。せっ かく計画的に開発を誘導しても，残された農地の 保全には繫がらないのである。

こうした事態を解決する方法として，M市は開 発区域内・外の土地交換を積極的に進めた。開発 区域内で土地売却を望まないものと, 区域外で売 却を望むものとの間で土地交換を行うことによっ て，まとまった開発用地の確保を可能にすると同 時に，開発区域に土地を持たない者の土地売却希 望も充たしたのである。

M市の土地交換で特筆すべき点としては, 開発 区域内・外の交換比率を $1 ： 1 の 「$ 等積交換」と したことが挙げられる。この方式を採用した背景 には,「集落のみんなが協力して土地を出し合って 行う開発だから, 開発区域から出る者, 開発区域 に入る者が対等な立場で交換する」という考え方 があった。この考え方は集落の寄り合いで確認さ れたもので, 集落内における開発利益の公平分配 を意味する。

\section{(2)除外規準のあり方}

M市では農振白地を縮小することで，農地のほ とんどは市街化調整区域と農用地区域の重複区域 に編入された。これによって, 農地を開発するに は(1)農振除外, (2)転用許可, (3)開発許可, (4)建築 確認の 4 つのハードルを越える必要があり, 制度 的規制の組み合わせとしては最も強力なものとな る。ところが，(1)から(4)のどの基準も「位置」の コントロール機能は十分とはいえない。そこで, M市は農振除外の局面で具体的な規準を設けるこ とによって開発位置のコントロールを実現させた のである。

M市が「位置」の規準として 2 辺接続条件を上 乗せしたことは，不適切な除外を防止するのに一 


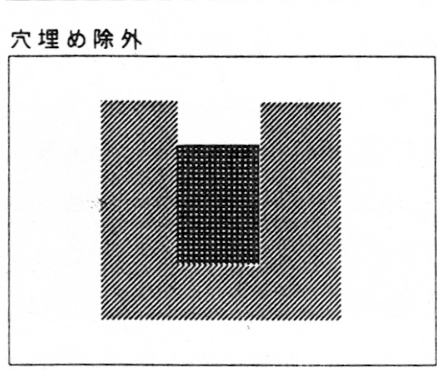

歯抜け除外

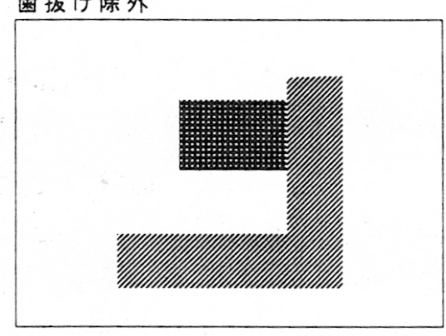

琒罡
角寄世除外

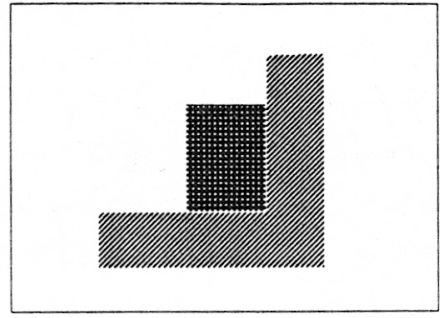

飛び除外

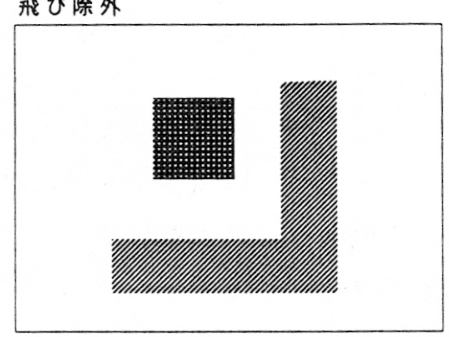

(3) 3 点セットによる総合的コントロール

M市の事例からもっとも学ぶべき点は, 独自の規準と計画的な開発誘導および土 地交換を組み合わせて土地利用のコント ロールを図っていることである。利用規 制・開発誘導・権利調整をいわば「3 点 セット」で用いることによって，これら を単独で用いるよりはるかに効果をあげ たと思われる。これは，図 4 に示すよう に，それぞれの手法が相互補完しあった ためである。

M市では独自規準によって農振白地・ 農振除外を厳しく規制したが，これは， 土地交換を行いながら開発を誘導するこ とによって, 農家の開発期待を公平に吸 収したからこそ可能であったといえよう。

図 3 農振白地との位置関係に着目した農振除外類型

定程度の効果をあ(゙た2)。独自の除外規準を作成 している市町村が数えるほどである状況を考えれ ば，大いに評価すべきではないかと考える。しか し，既存の道路・宅地への接続を条件としたこの 規準には，一つ解決しなけ札ばならない課題があ った。というのは，集落居住区から離れた既存宅 地に接続する除外の連鎖を排除できないことであ る。たとえば，図1のケースでいえば，宅地 $\mathrm{t}_{\mathrm{k}}$ に 接続した除外が申請された場合，それを排除する 根拠がないということである。

この問題を解決するには, (1)集落居住区から離 れた宅地への接続は認めないといった付帯条件を つける，(2)集落居住区との接続のあり方を規準と する，などの方法が考えられる。筆者らは集落居 住区を含めた既存の農振白地との接続形態によっ て農振除外を類型化し（図3)，うち「飛び除 外」,「歯抜け除外」は認めないといった除外規準 を提案している2)。市町村で独自規準を作成する 場合，これらを参考にしつつ，各市町村の地域条 件に適合したものを規準にすればよいと考える注8。

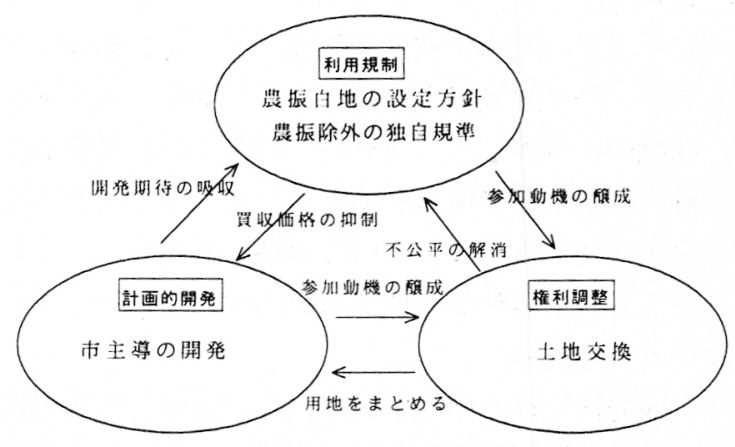

図 43 点セットの相互補完関係

\section{おわりに}

$\mathrm{JR}$ 北陸本線を金沢駅から上り列車に乗ると, $\mathrm{M}$ 市の土地利用がよくコントロールされていること を実感できる。金沢市と隣のN町を通過するうち は, 宅地と農地が混在する線路際の風景が飛び込 んでくるが，M市に入ると急に視界が開ける。農 地がまとまって保全されているのである。もちろ ん，開発されていないわけではない。まとまった 農地の向こうに住宅団地や工業団地が固まって存 在する。ただ，まとまっているとはいえ，訪れる 
たびに新たな開発が行われていた。これを繰り返 せば，最終的には農地はなくなってしまう。

筆者は，土地利用規制・計画的開発誘導・権利 調整を一体的に用いれば，現行制度のもとでも集 落土地利用のコントロールはある程度可能と考え る。ただし，この 3 点セットは両刃の剣である。 使い方をあやまれば，自治体による農地の大量潰 廃に繫がりかねない。そこで，土地利用コントロ 一ル手法 3 点セットを統御するものが今度は必要 となる。これこそが民主的手続きによる土地利用 構想・計画である。

\section{【注】}

1 ）本稿では「ゾーニング」を広く定義する。すなわち, 一定範囲の土地を複数の区域に区分して，それぞれの 区域に応じた利用規制を行うことによって土地利用の コントロールを面的に行う手法を指す。農振法のゾー ニングとは, ゾーニングのうち農振法にもとづくもの で，俗に「農振線引き」と呼ばれている。

2 ）農振白地には大きく分けて，(1)他法や具体的計画と競 合して農用地区域に設定できない夕イプ, (2)道路沿い, 集落居住区周辺など立地条件から将来の開発を見越し て農用地区域から予め除外した夕イプ, (3)農業生産上 の劣等農地が除外された夕イプ，がある。このうち， 土地利用秩序を保っていく上で最も問題なのは(2)の夕
イプである。農振白地といえども転用に際しては転用 許可をパスしなければならないが，事実上フリーパス 扱いしている自治体が少なくない。

3 ）農林事務次官通達48構改B第2308号「農業振興地域整 備の推進について」の俗称。

4 ) 除外申請を随時受けつける市町村もあれば, 年 2 〜 回と定期的に受けつける市町村もある。

5 ）農政局長通達47農政第1849号, 「調整通達」と呼ばれ る。機関委任事務から自治事務への移行に際し，この 通達がほぼこのままの形で法定化された。

6 ）国が定めたものを「基準」，自治体独自に作成したもの を「規準」と表記する。

7 ）新市町村農業振興地域整備計画（新農振計画）の策定 を契機とした。この事業は, 従来の農振計画では対象 としなかった生活環境を含んだ総合的な計画作成を目 的とする点に特徴があった。M市の独自規準の内容は, 新農振計画の考え方に影響されている。

8 ）農振白地を縮小できない市町村では, 農振白地内にお ける転用の適否判定に「位置」の規準を上乗せすれば よいと考える。

\section{【参考文献】}

1 ) 福与徳文：農振法のゾーニングに関する諸論点 の整理と展望, 農村計画学会誌15(1), pp.920 (1996)

2 ) 有田博之・福与徳文：集落空間の土地利用形成, 日本経済評論社, pp.1-237（1998） 